\title{
Multi-walled vs. single-walled carbon nanotube dispersions in nematic liquid crystals: comparative studies of optical transmission and dielectric properties
}

\author{
A.N.Samoilov, S.S.Minenko, A.P.Fedoryako, L.N.Lisetski, \\ N.I.Lebovka*, M.S.Soskin*" \\ Institute for Scintillation Materials STC "Institute for Single Crystals", \\ National Academy of Sciences of Ukraine, 60 Lenin Ave., 61001 Kharkiv, Ukraine \\ *F.Ovcharenko Institute of Biocolloidal Chemistry, National Academy of \\ Sciences of Ukraine, 42 Vernadsky Ave., 03142 Kyiv, Ukraine \\ *: Institute of Physics, National Academy of Sciences of Ukraine, \\ 46 Nauky Ave., 03028 Kyiv, Ukraine
}

\section{Received January 31, 2014}

\begin{abstract}
Comparative studies have been carried out of multi-walled and single-walled carbon nanotubes (CNT) dispersed in nematic liquid crystal matrix. Under strictly similar experimental conditions (5CB nematic host, the same supplier of CNTs, the same $50 \mu \mathrm{m}$ thick cell for optical and dielectric measurements, the same CNT concentration range, identical procedures of optical transmission vs. temperature and complex dielectric permittivity measurements), differences between single- walled and multi-walled CNTs were recorded. The most distinct differences were 3-4 times higher optical density and noticeably higher effect upon dielectric permittivity in the low-frequency range noted for single-walled CNTs, which could be clearly attributed to the difference in the specific surface area of single- and multi-walled carbon nanotubes.
\end{abstract}

Проведены сопоставительные исследования много- и одностеночных углеродных нанотрубок (УНТ), диспергированных в нематической жидкокристаллической матрице. При одинаковых әкспериментальных условиях отмечены различия между одностеночными и многостеночными УНТ. Наиболее существенными отличиями являются в 34 раза большая оптическая плотность в нематической фазе и значительно более сильное влияние на низкочастотную диэлектрическую проницаемость для одностеночных УНТ. Это может быть следствием различий в удельной площади для одно- и многостеночных углеродных нанотрубок.

Дисперсії багатостінкових та одностінкових вуглецевих нанотрубок в нематичних рідких кристалах: порівняльні дослідження оптичного пропускання та діелектричних властивостей. О.М.Салойлов, С.С.Міненко, О.П.Федоряко, Л.М.Лисецький, М.І.Лебовка, М.С.Соскін.

Проведено порівняльні дослідження багатостінкових та одностінкових вуглецевих нанотрубок (ВНT), диспергованих у нематичній рідкокристалічній матриці. В однакових експериментальних умовах відзначено різницю між багато- та одностінковими ВНТ. Найбільш істотною відмінністю є в 3-4 рази більша оптична густина у нематичній фазі та значно більший вплив на діелектричну проникність при низьких частотах при використанні одностінкових ВНТ. Це можна пояснити різницею у величинах питомої поверхні для однакових концентрацій одно- і багатостінкових нанотрубок. 


\section{Introduction}

Dispersions of carbon nanotubes (CNT) in liquid crystalline (LC) matrices have been generally recognized as highly promising materials for various applications in optical and electronic devices [1-4]. The main disadvantage of such materials, i.e., instability of their characteristics due to CNT aggregation in LC media, have been largely overcome by means of modification of the LC matrix composition and selection of appropriate CNT concentrations [5-8]. It should, however, be noted that in many recent publications on LC + CNT dispersions no distinction is made between single-walled and multi-walled carbon nanotubes (CWCNT and MWCNT) [9-11], though it is clear that for many applications this difference can be very important.

For our studies, we choose two characteristics, which could be considered as representative and physically significant, i.e., optical transmission in the vicinity of nematic to isotropic phase transition of nematic LC+CNT dispersions [12,13], and dielectric permittivity of the same systems. The latter characteristic seems to be especially interesting, since the question of the CNT effects upon dielectric permittivity of the nematic LC matrix seems to be rather contradictory, with positive or negative effects obviously depending on various parameters of the matrix and measurement conditions $[10,14-16]$.

The question of optical transmittance in LC dispersions of CNT can already be of practical importance for LC-based opto-electronic devices. Thus, the effect of UV radiation-induced changes in the helical pitch value and texture of cholesteric LC [17] was shown to be modified by the dispersed CNTs, with the effects of UV radiation being significantly attenuated [18].

In our studies, we used a standard nematic 5CB as matrix, with different concentrations of single- and multi-walled carbon nanotubes dispersed therein. Optical transmission and dielectric permittivity were measured under the same conditions for all the samples.

\section{Materials and methods}

In our experiments, we used the nematic 5CB of $99.5 \%$ purity (Chemical Reagents Plant, Ukraine) undergoing the nematic-isotropic transition at $T_{\mathrm{NI}} \sim 308-309 \mathrm{~K}$ and the crystal-nematic transition (melting) at $T_{\mathrm{CN}}=295.5 \mathrm{~K}$. The carbon nanotubes - multi-walled (MWCNT) of diameter $d \sim 10 \mathrm{~nm}$ and length $l \sim 5-10 \mu \mathrm{m}$, and single-walled (SWCNT) of $d \sim 1.5 \mathrm{~nm}$ and $l \sim 5-10 \mu \mathrm{m}$ were obtained from Arry, Germany. The LC + CNT dispersions were obtained by adding the appropriate weights of the nanotubes to the LC solvent in the isotropic state with subsequent $20-30 \mathrm{~min}$ sonication of the mixture using a UZD-22/44 ultrasonic disperser (Ukrrospribor, Sumy, Ukraine), in accordance with procedure essentially similar to the previously described $[12,19,20]$.

The optical transmission was measured using a Shimazu UV-2450 (Japan) spectrophotometer at $700 \mathrm{~nm}$ wavelength (which was shown to be far from possible absorption bands of the LC host). A sandwich-type LC cell of $50 \mu \mathrm{m}$ thickness was used. The sample was introduced between the cell walls using the capillary forces at the temperature of $\sim 313 \mathrm{~K}$, i.e., in the isotropic phase just above the phase transition from the nematic. The measurements were done within the temperature range $290-310 \mathrm{~K}$ in the heating and cooling modes, and the temperature was stabilized using a flowingwater thermostat $( \pm 0.1 \mathrm{~K})$.

The real and imaginary components of dielectric permittivity in the region below $30 \mathrm{MHz}$ were measured by the oscillographic method. By measuring the voltage and current through the sample studied, the cell capacitance and dielectric loss were determined. From the values of $C_{\text {cell }}$ and $\operatorname{tg} \delta$ (obtained from the phase difference between voltage and current), $C_{\text {sample }}$ was found as $C_{\text {sample }}=C_{\text {cell }} / \sqrt{(1+\operatorname{tg} \delta)}$. Then, with $C_{0}$ as the empty cell capacitance, $\varepsilon^{\prime}=C_{\text {sample }} / C_{0}$, and $\varepsilon^{\prime \prime}=\operatorname{tg} \delta \cdot \varepsilon^{\prime}$. At frequencies above $30 \mathrm{MHz}$, we used an E7-11 type Q-meter.

\section{Results and discussion}

The results obtained from optical transmission measurements in the nematic phase are shown in Fig. 1.

The optical density values were calculated as $D=-\lg (T / 100)$, where $T$ is the measured optical transmission value (in percentage terms) with respect to the incident light intensity for otherwise similar samples with and without dispersed nanotubes. It can be seen that the optical density generally follows the Bouguer-Lambert-Beer law, being (upon correction for non-ideal transmission of the undoped sample) roughly proportional to CNT concentration. The effective extinction coefficient (i.e., the slope of the linear $D(c)$ plot at a constant cell 
thickness) is about three times higher for SWCNT as compared with MWCNT. However, this difference completely disappears in the isotropic phase (Fig. 2), with transmittance values at the same concentrations of either type nanotubes being the same within experimental errors.

Thus, the observed difference appears only in the nematic phase, i.e., when carbon nanotubes are subject to orientational ordering imposed by the liquid crystalline structure of 5CB. Further reasoning suggests that single-walled CNTs have much larger specific surface area as compared to dispersion with the same volume/mass fraction of MWCNTs. (Another formally possible reason could be the use of mass, and not volume, concentrations for the $D(c)$ plots; however, the difference in SWCNT and MWCNT densities is relatively small [21] and cannot give rise to such large difference in extinction).

As the next step in our studies, we made an attempt to clear up the situation with effects of CNT on dielectric properties of nematic LC. The available picture was, in fact, rather contradictory, with introduction of CNT causing, according to various reports $[10,14-16]$, either an increase in dielectric permittivity or, on the contrary, its lowering. One could assume the role of ionic impurities in the LC matrix, and different behavior at low and high frequencies was also noted [10].

Since we worked with planar texture of the nematic phase of $5 \mathrm{CB}$, which was deliberately formed in our cells, we measured only the perpendicular component $\varepsilon_{\perp}^{\prime}$ of an-

isotropic dielectric permittivity. The results obtained are shown in Fig. 3.

It is clearly seen that the difference in the obtained values between the pristine $5 \mathrm{CB}$ and $5 \mathrm{CB}$ doped with carbon nanotubes is very large in the low-frequency part of the dielectric spectrum. The observed increase in $\varepsilon_{\perp}^{\prime}$ at low frequencies can be natu-

rally ascribed to ions moving in the vicinity of a surface - of the surfaces of the cell electrode in the case of nematic 5CB, and, in the presence of dispersed nanotubes, of the cylindric surfaces of CNTs.

In the high-frequency range the difference is not significant - the role of ions and surfaces is felt only at lower frequencies. And it is quite natural that the measured dielectric permittivity is noticeably higher for dispersions with single-walled CNTs due to their larger specific surface

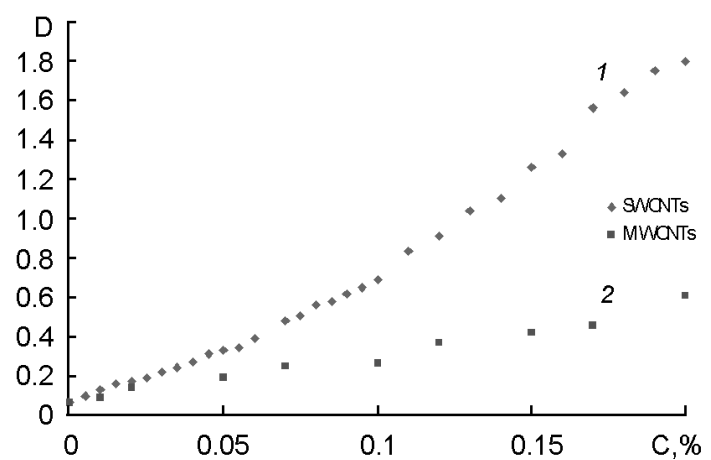

Fig. 1. Optical density as function of singleand multi-walled CNT concentration in the nematic phase of $5 \mathrm{CB}\left(28^{\circ} \mathrm{C}\right): 1-\mathrm{SWCNT}$; 2 - MWCNT.

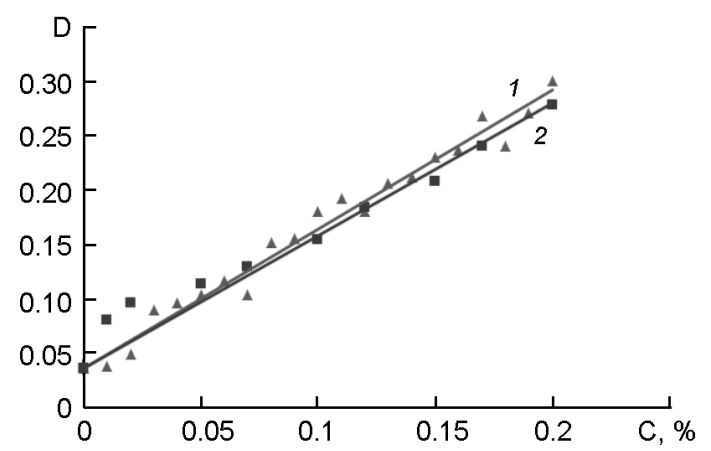

Fig. 2. Optical density as function of singleand multi-walled CNT concentration in the isotropic phase of $5 \mathrm{CB}$ in $\left(38^{\circ} \mathrm{C}\right): 1-$ SWCNT; 2 - MWCNT.

area at the same CNT concentration. This is in full agreement with the results obtained for optical transmission - the optical density was substantially higher for SWCNT due to the same reason, i.e., larger specific surface area.

In the same experiments, the imaginary components of the perpendicular dielectric permittivity $\varepsilon_{\perp}^{\prime \prime}$ were also measured (Fig. 4).

For 5CB and 5CB dispersions of carbon nanotubes frequencies related to vibrational movements of CNTs were revealed. The characteristic relaxation frequency was $3 \mathrm{kHz}$ for $5 \mathrm{CB}+\mathrm{MWCNT}, 15 \mathrm{kHz}$ for $5 \mathrm{CB}+\mathrm{SWCNT}$, and $8 \mathrm{MHz}$ for undoped $5 \mathrm{CB}$, which looks quite as could be expected.

It can be noted that in our experiments the introduction of nanotubes resulted in higher dielectric permittivity in the low frequency range (Fig. 3), while measurements under apparently similar conditions led to lowering of dielectric permittivity due to the CNT role as traps for charge 


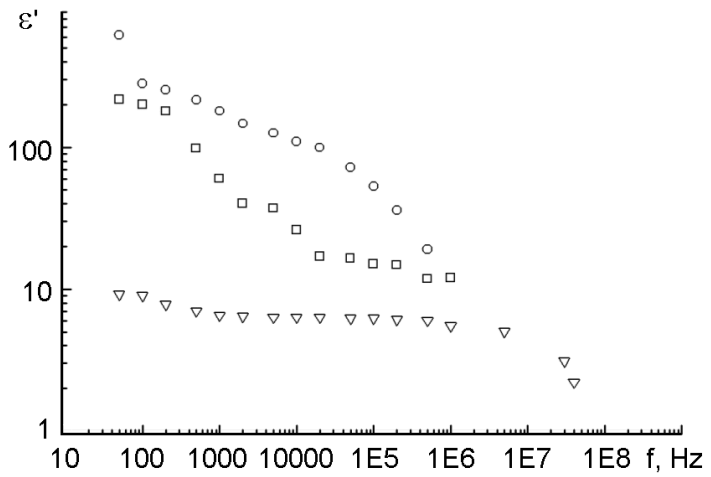

Fig. 3. Frequency dependence of $\varepsilon_{\perp}^{\prime}$ for nematic 5CB doped with $0.01 \%$ CNT: $\bigcirc-$ SWCNT, $\square-$ MWCNT, $\nabla-$ undoped 5CB.

carriers [10]. The apparent discrepancy can be easily explained - in our case, the SWCNT sample purity was not so high, and the impurities could reveal themselves in the LC+CNT dispersion as additional charge carriers counteracting and even reversing the initially expected effect. Thus, in further studies of dielectric properties of LC+CNT dispersions, one should account, alongside with frequency range and the presence of impurities in the LC matrix, for the impurities coming from the CNT itself.

\section{Conclusions}

Thus, we have carried out comparative measurements of two important characteristics - optical transmission and dielectric permittivity - for nematic matrix 5CB with dispersed single- and multi-walled carbon nanotubes. All experimental parameters - the nematic matrix, concentration of nanotubes, ultrasonication procedure, cell geometry and thickness, method of introduction of the dispersion into the cell, measuring equipment and measurement conditions for determination of optical transmission and dielectric permittivity, etc. were, within inevitable errors, identical for SWCNT and MWCNT.

The two important parameters - the slope of the optical density vs. CNT concentration dependence (the effective extinction coefficient) and the perpendicular component of the real dielectric permittivity $\varepsilon_{\perp}^{\prime}-$ have been shown to be very sensitive to the CNT nature, i.e., at the same mass/volume concentration the effects of single-walled CNTs were much stronger. This can be naturally related to larger specific surface

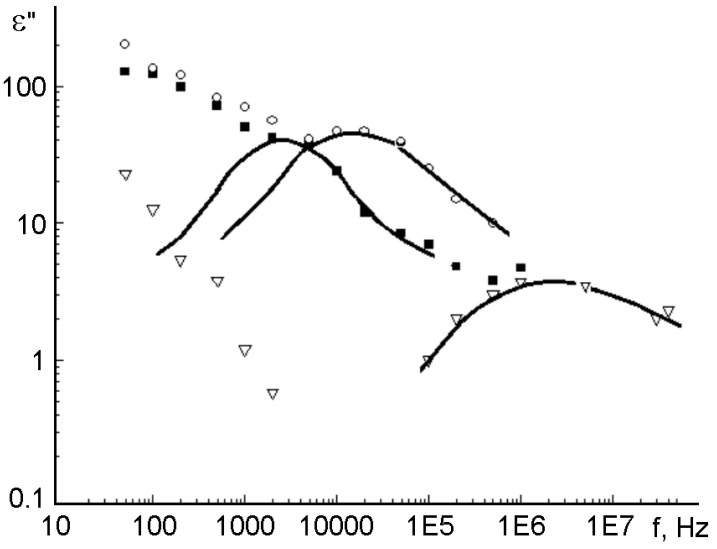

Fig. 4. Frequency dependence of $\varepsilon_{\perp}^{\prime \prime}$ for nematic 5CB doped with $0.01 \%$ CNT: $\bigcirc-$ SWCNT, $\square-$ MWCNT, $\nabla-$ undoped 5CB.

area of single-walled nanotubes as compared with similar multi-walled ones.

\section{References}

1. M.Rahman, W.Lee, J.Phys. D:Appl.Phys., 42, 063001 (2009).

2. O.Stamatoiu, J.Mirzaei, X.Feng, T.Hegmann, Top. Curr. Chem., 318, 331 (2012).

3. J.P.F.Lagerwall, G.Scalia, Curr.Appl.Phys., 12, 1387 (2012).

4. S.Schymura, G.Scalia, Phil.Trans.Roy.Soc.A, 371, 2012021 (2013).

5. M.Kuhnast, C.Tschierske, J.Lagerwall, Chem. Commun., 46, 6989 (2010).

6. Y.Ji, Y.Y.Huang, E.M.Terentjev, Langmuir, 27, 13254 (2011).

7. L.N.Lisetski, N.I.Lebovka, S.V.Naydenov, M.S.Soskin, J. Mol. Liq., 164, 143 (2011).

8. N.I.Lebovka, L.N.Lisetski, M.I.Nesterenko et al., Liq. Cryst., 40, 968 (2013).

9. S.K.Prasad, M.V.Kumar, C.V.Yelamaggad, Carbon, 59, 512 (2013).

10. F.-C.Lin, P.-C.Wu, B.-R.Jian, W.Lee, $A d v$. Cond. Matt. Phys. (Hindawi), 2013, Art. ID 271574 (2013).

11. C.Cirtoaje, E.Petrescu, C.Motoc, Physica E, 54, 242 (2013).

12. A.I.Goncharuk, N.I.Lebovka, L.N.Lisetski, S.S.Minenko, J.Phys.D:Appl.Phys., 42, 165411 (2009).

13. L.N.Lisetski, S.S.Minenko, A.P.Fedoryako, N.I.Lebovka, Physica E, 41, 431 (2009).

14. O.Trushkevych, F.Golden, M.Pivnenko et al., Electron. Lett., 46, 693 (2010).

15. B.-R.Jian, C.-Y.Tang, W.Lee, Carbon, 49, 910 (2011).

16. A.Y.-G.Fuh, W.Lee, K.Y.-C.Huang, Liq. Cryst., 40, 745 (2013).

17. I.Gvozdovskyy, O.Yaroshchuk, M.Serbina, R.Yamaguchi, Opt. Express, 20, 3499 (2012). 
18. O.Yaroshchuk, S.Tomylko, I.Gvozdovskyy, R.Yamaguchi, Appl.Optics, 52, E53 (2013).

19. L.N.Lisetski, S.S.Minenko, V.V.Ponevchinsky, et al., Mat.Sci.Eng. Technol., 42, 5 (2011).
20. L.N.Lisetski, S.S.Minenko, A.V.Zhukov, et al., Mol.Cryst.Liq. Cryst., 510, 43 (2009).

21. C.Laurent, E.Flahaut, A.Peigney, Carbon, 48, 2994 (2010). 